Рейла О., Івлєва К., Гулієва $\Lambda$. Використання автентичних матеріалів ...

УДК 811.111:378.147:80-057.87

DOI https://doi.org/10.24919/2308-4863.3/23.166819

Ольга РЕЙДА,

orcid.org/0000-0003-2227-7994

асистент кафедри іноземних мов

Білоцерківського начіонального аграрного університету

(Біла Церква, Украӥна) milarejda@теta.иа

Катерина ІВЛЕВА,

orcid.org/0000-0002-9539-4086

старший викладач кафедри

інтелектуальних комп 'ютерних систем

Начіонального технічного університету

«Харківський політехнічний інститут»

(Харків, Україна)ihgfedcba@ukr.net

Діна ГУЛІЕВА,

orcid.org/0000-0001-8310-745X

старший викладач кафедри

інтелектуальних комп'ютерних систем

Начіонального технічного університету

«Харківський політехнічний інститут»

(Харків, Україна)dgulieva@ukr.net

\title{
ВИКОРИСТАННЯ АВТЕНТИЧНИХ МАТЕРІАЛІВ У ПРОЦЕСІ ВИКЛАДАННЯ АНГЛІЙСЬКОЇ МОВИ СТУДЕНТАМ-ФІЛОЛОГАМ
}

У статті зроблена спроба розглянути питання використання автентичних матеріалів у процесі навчання англійській мові студентів філологів, дано визначення поняттю «автентичні матеріали» та «навчально-автентичні матеріали». В рамках статті представлені головні аспекти використання автентичних матеріалів та пропонуються етапи роботи з автентичними матеріалами (підготовчий етап, етап безпосередньої роботи з матеріалом (текстовий), етап обговорення та творчий етап), запропоновані вправи до кожного етапу та визначені умови результативного використання автентичних матеріалів на занятті. Використання автентичних матеріалів у процесі підготовки студентів-філологів розглядається як засіб розвитку всіх компонентів іншомовної комунікативної компетенції: мовного, мовленнєвого, соціокультурного, компенсаторного, академічного компоненту.

Ключові слова: іншомовна комунікативна компетенція, студент-філолог, англійська мова, автентичний матеріал, навчально-автентичний матеріал, міжкультурна комунікація, когнітивні вміння.

Olga REJDA, orcid.org/0000-0003-2227-7994

Assistant of the Foreign Languages department,

Bila Tserkva National Agrarian University

(Bila Tserkva, Ukraine) milarejda@meta.ua

Kateryna IVLIEVA, orcid.org/0000-0002-9539-4086 Senior Lecturer,

department of Intelligent Computer Systems, National Technical University "Kharkiv Polytechnic Institute» (Kharkiv,Ukraine)ihgfedcba@ukr.net

Dina GULIEVA, orcid.org/0000-0001-8310-745X Senior Lecturer, department of Intelligent Computer Systems, National Technical University «Kharkiv Polytechnic Institute» (Kharkiv,Ukraine)dgulieva@ukr.net 


\section{AUTHENTIC MATERIALS USING IN THE PROCESS OF ENGLISH LANGUAGE TEACHING TO STUDENTS PHILOLOGISTS}

The article aims to consider the authentic materials using in the process of English language teaching to students philologists, the concept of "authentic materials" and concept of "training and authentic materials" has been defined. It has been emphasized that text material can also be used in class according to modern methods of teaching English, which is specially developed or processed by methodologists in order to adapt it to the specific needs of students: the definitions of these texts has been presented: (semi-authentic texts, edited authentic texts, approximately-turned authentic texts, near-authentic texts, authentic-looking texts, learner authentic texts). The main aspects of authentic materials using and working phases with authentic materials (preparatory stage, the stage of direct work with training material (text), the discussion stage and creative stage) have been presented in this article, the exercises for each stage are proposed and the requirements for the successful use of authentic materials in the classroom have been listed. The authentic materials using of students philologists training are considered as a means of all components development of foreign language communicative competence: language, speech, social and cultural, compensatory and training components; forms of lexico-grammatical, intonational, speech, emotional example, restores the usual conditions of real communication, reflecting both the real situations and imaginary ones. The authentic materials linking the elements of the lesson can organize and regularize the training stages. In addition, they are a synthesis of visual, acoustic, motor, speech, situational, detail and figurative demonstrativeness. The article analyzes the specifics of the authentic materials selecting for the purposes of its using in English classes in the training process, the requirements have been listed: authenticity, functionality (different themes and genres of authentic materials, their meaningful significance), didactic and cognitive value of the authentic resources. The article mentioned the active practice of authentic materials using in teaching English to students is limited by the level of students' language knowledge and certain difficulties concerning socio-cultural aspect.

Key words: foreign-language communicative competence, student philologist, English, authentic material, educational and authentic material, intercultural communication, cognitive competence.

Постановка проблеми. Сьогодні спосте рігається стрімке зростання міжнародних взаємозв'язків в економічній області, громадському та культурному житті України, простежується тенденція збільшення свободи пересування фахівців, підвищується освітня значущість вивчення англійської мови внаслідок необхідності володіти конкретними уміннями, які потрібні для комунікації в країнах Свропейського Союзу. На сучасному етапі спостерігається зміна парадигми вищої освіти в Україні, а це, у свою чергу, змінює головні цілі й зміст процесу навчання, що веде за собою відмову від застарілих стандартів, традиційних систем та перехід до структур, які є більш динамічними й гнучкими та можуть реагувати на зміни навколишнього глобального простору.

Сьогодні студенти-філологи повинні не лише мати весь комплекс загальнокультурних й професійних компетенцій у сфері виробничо-практичної, науково-методичної, науково-експериментальної й координаційно-адміністративної діяльності. Згідно $з$ новітніми цільовими установками викладачеві англійської мови необхідно вибирати такі методи, форми, засоби й зміст навчання, які зможуть гарантувати результативне оволодіння закономірностями функціонування мови, яка вивчається, а також ключовими логічними методами здійснення комунікативних цілей висловлювання, відмінними рисами офіційного, нейтрального й неофіційного регістру комунікації.

Аналіз досліджень. Особливе положення у формуванні вмінь реалізовувати міжкультурну комунікацію, в залученні студентів до іншомовної культури, активізації когнітивного інтересу та самостійності у процесі вивчення англійської мови, безумовно, займає використання на занятті автентичних матеріалів. Сьогодні автентичні матеріали застосовуються у процесі розвитку іншомовної комунікативної компетенції студентів-філологів все частіше. Проведення заняття повністю англійською мовою, використання автентичних матеріалів дозволяє створювати модель іншомовного середовища, створює умови реального спілкування англійською мовою. Вітчизняні й закордонні методисти вказують на те, що застосування різних видів автентичних матеріалів у навчальному процесі сприяє зростанню комунікативно-пізнавальної мотивації, розвитку лінгвокраїнознавчої компетенції, однозначно впливає на емоційний стан студентів, гарантує можливість синхронного звернення як до мови, так і до культури (Н. В. Баришників, М. В. Плеханова, Р. П. Мільруд, Е. В. Носонович, L. Lier, M. P. Breen, J. Harmer, H. Hofmann, R. Scarcella, G. Neuner, D. A. Wilkins).

На сучасному етапі викладачі англійської мови активно застосовують у навчальному процесі підручники закордонних видавництв та вітчизняні методичні розробки, які були створені на базі текстів із закордонної преси, художньої літератури та інших оригінальних джерел. Значно зростає кількість аудіо- та відеоматеріалів, які використовуються на заняттях 3 англійської мови. Проте загальноосвітні можливості автентичних матері- 
алів у процесі іншомовної підготовки студентівфілологів використовуються недостатньо, методи роботи 3 ними неваріативні, що робить актуальною проблему розробки цілісної концепції роботи 3 автентичними матеріалами на заняттях $з$ англійської мови в мовному внз.

Мета статті - проаналізувати питання використання автентичних матеріалів у процесі навчання англійській мові студентів-філологів, дати визначення поняттям «автентичні матеріали» та «навчально-автентичні матеріали». Розглянути етапи роботи з автентичними матеріалами, вправи до кожного етапу та визначити умови результативного використання автентичних матеріалів на занятті.

Виклад основного матеріалу. Попри достатню кількість методичних робіт, які розглядають питання автентичності, немає універсального визначення поняття автентичних матеріалів. Носонович Е. В. та Мільруд О. П. вважають, що навчати іноземній мові слід на автентичних матеріалах, а саме матеріалах, які походять із оригінальних джерел та не призначаються для учбових цілей. Проте вони вказують, що ці матеріали не завжди відповідають певним завданням й умовам навчання, а іноді є досить складними в мовленнєвому аспекті. Тому автентичний матеріал умовно можна поділити на навчально-автентичний та автентичний.

Автентичні матеріали - це матеріали 3 оригінальних джерел, які мають природне лексичне наповнення й граматичні форми, характеризуються ситуативною адекватністю вживаних мовленнєвих засобів, показують випадки автентичного слововживання. Дані матеріали спеціально не призначені для навчальних цілей, проте можуть застосовуватися у процесі навчання англійській мові. Навчально-автентичні матеріали - це матеріали, які створюються спеціально, враховуючи абсолютно всі характеристики автентичного учбового процесу й критерії автентичності, такі матеріали призначаються для вирішення певних навчальних завдань.

Автентичні матеріали - це не тільки матеріали, які були створені носіями мови для носіїв, наприклад: художні твори, журнальні та газетні статті, тематичні блоги, подкасти, рекламні оголошення та інше. В сучасній методиці навчання англійській мові також можливо використовувати на аудиторних заняттях текстовий матеріал, який спеціально розробляється або переробляється методистами 3 метою адаптувати його до потреб студентів. У роботах іноземних авторів можна знайти такі визначення для позначення подібних текстів:
1) semi-authentic texts - тексти, які створюються на основі оригінального матеріалу, але адаптуються до програми навчання в лексичному чи синтаксичному аспекті;

2) edited authentic texts - автентичні тексти, які були відредаговані;

3) roughly-turned authentic texts - автентичні тексти, які були відредаговані, але в яких рівень граматики трохи вище рівня, який мають студенти;

4) near-authentic texts - тексти, які максимально наближені до автентичних;

5) authentic-looking texts - тексти, які виглядають як автентичні тексти;

6) learner authentic texts - навчально-автентичні тексти (Яковлева, 2010: 112).

Використання автентичних матеріалів на заняттях з англійської мови формує лексико-граматичний, інтонаційний, вимовний мовленнєвий приклад; відновлює умови звичайної комунікації, відображаючи як реальні ситуації, так і вигадані; презентує інформацію про країну мови, що вивчається, що сприяє побачити ситуацію, яка представлена в тексті, найточніше. Також автентичні матеріали гарантують «ефект присутності», або «ефект співучасті»; активізують мовленнєву активність, містять великі мотиваційні можливості. Автентичні матеріали зв'язують елементи аудиторного заняття, можуть упорядковувати та систематизувати етапи навчання. Крім того, вони є синтезом візуальної, акустичної, моторної, мовленнєвої, ситуаційно-модельної, предметної, образної наочності; працюють як засіб дистантного занурення в природне мовленнєве середовище на абсолютно всіх стадіях навчання англійській мові. Активне використання автентичних матеріалів на заняттях 3 англійської мови допомагає активізувати пізнавальну діяльність студентів-філологів, збільшити роль самостійної роботи, сформувати у студентів спостережливість, уяву, увагу, мислення, мовленнєву пам'ять; розвивати вміння в усіх без виключення видах мовленнєвої діяльності, креативній діяльності студентів, що характеризується перенесенням знань та умінь в нову ситуацію.

Автентичні матеріали у процесі вивчення англійської мови підвищують впевненість та досвід «реальної» мови студентів із підтримкою конструктивного зворотного зв'язку. Основні переваги їх використання очевидні:

1. Використовуючи автентичні матеріали, студенти мають змогу вивчити лексичні одиниці та конструкції, які вони, ймовірно, ніколи не побачать у навчальних посібниках з англійської мови. Вони мають шанс вивчити абревіатури під час 
перегляду текстового матеріалу; почути справжню тональність, побачити мову тіла носіїв мови автентичного матеріалу. Під час прослуховування автентичного аудіоджерела студентам також доводиться фільтрувати фонові шуми, а іноді дійсно концентруватися, щоб зрозуміти людей, які розмовляють один 3 одним. Це може виявитися складніше, ніж адаптовані навчальні аудіозаписи.

2. Автентичні матеріали, безсумнівно, знайомлять студентів-філологів із культурою англомовних країн, оскільки вони оволодівають змістом, а не лише спостерігають, як використовується англійська мова.

3. Автентичні матеріали підвищують мотивацію студентів та краще задовольняють їх потреби. Мета використання автентичних ресурсів полягає в тому, щоб зрозуміти та вживати англійську мову в реальних комунікативних ситуаціях.

Відбираючи автентичні матеріали для використання на заняттях 3 англійської мови у процесі підготовки студентів-філологів, необхідно враховувати вимоги автентичності, функціональність (різні теми та жанри матеріалів, їх змістовна значущість), дидактичну та пізнавальну цінність матеріалу. Автентичні матеріали можуть включати:

1. Listening: телешоу, радіо ефіри, телереклама, випуски новин, телефонні повідомлення, фільми художні та документальні, кліпи, мультфільми та інше.

2. Visual: фотографіï, твори мистецтва, знаки 3 символікою, листівки, ілюстровані книги та інше.

3. Printed: меню ресторану, статті газети, оголошення на дошках оголошень, сайти компанії, талони, каталоги продажів, туристичні брошури, карти меню та рахунки, телефонні книги, знаки, блоги, плакати фільму, етикетки їжі та інше.

Під час використання автентичних матеріалів на заняттях 3 англійської мови викладачеві необхідно максимізувати їх переваги, оцінюючи зміст та читаність цих навчальних матеріалів:

1. Актуальність та цікавий контент. Викладачу треба намагатися відбирати теми, які відповідають вимогам студентів філологів, матеріал має бути практичним, активізувати зацікавленість студентів, допомагати їм побачити актуальність занять з іноземної мови в реальному житті.

2. Зміст автентичного матеріалу необхідно розбивати на відповідні фрагменти. Робота 3 автентичними матеріалами не повинна тривати занадто довго та займати весь аудиторний час.

3. Викладачу необхідно відбирати лінгвістично відповідний матеріал. Перш ніж використовувати автентичні матеріали на занятті, треба переконатися, що вони відповідають навчальному плану, навчають незнайомій лексиці, пояснюють складну концепцію або закріпляють тему, яка вже опрацьована.

Робота 3 автентичними матеріалами включає nідготовчий етап, етап безпосередньої роботи з матеріалом (текстовий), етап обговорення та творчий eman. Під час роботи 3 прислів'ями та наочним матеріалом певні етапи відсутні.

Основні завдання підготовчого етаny - виключення вірогідних труднощів сприйняття автентичних матеріалів (мовленнєвих, стилістичних та соціокультурних), ознайомлення 3 метою читання, перегляду та прослуховування, формування стимулу до діяльності (зацікавити, здивувати), стимуляція ментальних можливостей студентів-філологів. Цей етап припускає формування вмінь передбачати, будувати речення, спираючись на ілюстрації, схеми, мовленнєві кліше та не використовуючи опору, запам'ятовувати слова та фрази англійською мовою.

Підготовку до безпосередньої роботи з автентичними матеріалами можливо реалізувати самостійно або разом із викладачем, використовуючи список питань, worksheets або вправи, наприклад: перевести заголовок; визначити значення слів по визначеннях; заповнити пропуски; відповісти на питання; виконати тестові завдання та ін.

Eman безпосередньої роботи з матеріалом націлений на розвиток умінь семантичного перероблення отримуваної інформації (розуміти основну ідею матеріалу, визначати межі підтем, вибудовувати структуру та план матеріалу), розрізняти нюанси в мовній/немовній поведінці носіїв англійської мови та поведінці носіїв української мови.

Відбираючи завдання на цьому етапі, необхідно враховувати те, які саме автентичні матеріали (матеріал треба дивитися, слухати або читати) та завдання (часткове або повне охоплення змісту, пошукове або вивчаюче читання та інше) використовуються.

Післятекстовий eman припускає рішення таких завдань: провести відбір головної інформації або фактів, згадати окремі деталі, проконтролювати розуміння матеріалу. Цей етап призначений для формування вмінь рецептивного характеру, які мають на увазі отримання найважливішої інформації, розуміння змісту, розвиток когнітивних умінь (вибір, моніторинг, прогнозування, аналіз, порівняння), вмінь репродуктивного характеру (передати короткий зміст матеріалу, використовуючи опору та без неї), вмінь мовленнєвого етикету (як правильно почати та закінчити розмову, погодитися або не погодитися $з$ думкою іншої людини та інше). 
Для цього етапу можливо використовувати такі вправи: обговорити ситуацію; заповнити пропуски в тексті; worksheets, тестові завдання, переклад, знайти еквіваленти; скласти план; визначити головну ідею; відповісти на питання; заповнити таблицю.

Творчий етап включає завдання розвитку креативних здібностей студентів-філологів, навчання самостійному пошуку, використання соціокультурної інформації та іï інтерпретації. Цей етап має на меті сформувати у студентів уміння репродуктивного характеру (інтерпретація тексту), вміння продуктивного характеру (застосування інформації в різноманітних ситуаціях комунікації), вміння використати соціокультурні одиниці згідно із завданнями комунікації, вміння мовленнєвого етикету, оцінювання та узагальнення інформацію.

На даному етапі слід використовувати такі пізнавально-пошукові та пізнавально-дослідницькі завдання, як: трансформація матеріалу (наприклад, проглянувши теленовини, письмово передати зміст передачі); відтворення тексту (переказати, резюмувати, описати матеріал та інше); рішення проблемних завдань (зробити вибірку інформації $з$ конкретною метою, провести аналіз, надати докази або спростувати інформацію, виділити головне або важливе); проектні завдання (проекти, тематичні повідомлення та інше).

Певні автентичні матеріали нерідко включають лексичні одиниці, які відсутні в темі, що вивчається, тому студенти можуть їх не зрозуміти, також вони включають велику кількість різноманітної візуальної, вербальної та звукової інформації, яка може викликати складнощі під час аудиторного заняття. Відбір змісту навчання за вищезгаданими критеріями допоможе впоратися 3 тематичною багатоплановістю автентичних матеріалів та спростити їх взаємодію з лексичною темою, що вивчається в цей період. Системна робота з автентичними матеріалами на заняттях 3 англійської мови дозволяє істотно збільшити час усної мовленнєвої практики кожного студента на занятті, ментальна діяльність студентів активується, підвищується мотивація до вивчення культури англомовної країни, формуються комунікаційні уміння, підтримується постійний обмін знаннями. Від етапу до етапу у студентів формуються вміння іншомовної комунікації, кількість висловлювань студентів англійською мовою збільшується, пройдений лексичний та граматичний матеріал активізується, i, таким чином, процес навчання англійській мові стає значно ефективнішим.

Отже, автентичні друковані матеріали сприяють розумовій та мовленнєвій діяльності студен- тів, можуть допомогти формуванню фонетичних навичок та розширенню вокабуляра студентів, призначаються для успішнішого розуміння культури англомовної країни. Пісні англійською мовою підвищують зацікавленість не лише до країни мови, що вивчається, але й до самої мови, допомагають удосконалювати навички вимови та краще засвоїти й розширити вокабуляр, підтримують на занятті позитивний психологічний мікроклімат та стимулюють студентів до монологу та діалогу. Автентичні аудіоматеріали допомагають сформувати у студентів аудитивні навички й уміння, готують їх до комунікації у природних умовах завдяки ситуативного характеру, актуальності і комунікативній орієнтованості автентичних завдань. Автентичні відеоматеріали включають візуальну інформацію щодо невербальної поведінки носіїв мови, підтримують мотивацію студентів та активізують їх академічну та комунікативну діяльність. Автентичний наочний матеріал допомагає підвищити зовнішню мотивацію до вивчення англійської мови, презентує життя народів, надає умови для мовленнєвої взаємодії та робить можливим креативний розвиток студентів.

Наприклад, на онлайн-платформі FluentU міститься великий вибір автентичних відео, на якій автори беруть реальний відеоматеріал (музичні кліпи, трейлери фільмів, новини, бесіди) та перетворюють їх на спеціальні заняття 3 вивчення англійської мови. Студенти мають можливість переглядати відео за складністю, темами («Мистецтво та розваги», «Здоров'я й спосіб життя» та інше) та форматом (відеоблог, новини, шоу та інше). «Режим навчання» FluentU враховує історію переглядів студентів, пропонуючи відповісти на питання на основі вивченого матеріалу, що налаштовує студентів на успіх.

Але, попри вищезгадані переваги автентичних ресурсів на заняттях 3 англійської мови, не існує єдиної точки зору щодо їх застосування. Активна практика використання автентичних матеріалів під час навчання англійській мові студентів-філологів поза мовленнєвого середовища обмежується рівнем знань студентів та певними труднощами соціокультурного аспекту, з якими студенти можуть зіткнутися у процесі роботи з автентичними ресурсами.

Деякі автори вважають, що можуть виникнути певні складнощі з використанням автентичних ресурсів у процесі викладання англійської мови:

1) наявність великої кількості різноманітного візуального, вербального та звукового матеріалу, який студент не може обробити під час аудиторного заняття; 
2) спостерігається тематична багатоплановість, яка ускладнює узгодженість автентичної інформації 3 лексичною або граматичною темою, яка вивчається на цей момент (Тарнопольский, 2006: 156).

Приймаючи до уваги вищезгадані проблеми, деякі автори пропонують опрацьовувати тексти, які не призначені для ненавчальних цілей, водночас не порушуючи їх автентичності, та створювати тексти для навчальних цілей, ураховуючи абсолютно всі характеристики автентичного навчального матеріалу.

Внаслідок цього можна прийти до висновку, що не існує загальновстановленого визначення поняття автентичних матеріалів, їх систематизації та єдиної точки зору щодо їх застосування у процесі навчання англійській мові у вітчизняній та закордонній методиці.
Висновки. Використання автентичних матеріалів у процесі підготовки студентів-філологів розглядається як засіб розвитку всіх компонентів іншомовної комунікативної компетенції: мовного (скоромовки, прислів'я та приказки, вірші, автентичні тексти, аудіо та відео матеріали), мовленнєвого (автентичні надруковані, наочні, пісенні матеріали, аудіо та відеоматеріали), соціокультурного, компенсаторного (автентичні наочні матеріали, відеоматеріали), академічного (автентичні надруковані матеріали, аудіо та відеоматеріали). Автентичні матеріали дають можливість формувати актуальні, спонтанно виникаючі і такі, що визначають інтенсивну навчально-пізнавальну діяльність, ситуації міжкультурної комунікації.

\section{СПИСОК ВИКОРИСТАНИХ ДЖЕРЕЛ}

1. Закон України «Про вищу освіту». URL : http://zakon2.rada.gov.ua/laws/show/1556-18.

2. Тарнопольский О. Б. Методика обучения иноязычной речевой компетентности в высшем учебном заведении : обр. учебник. Київ : Фирма «Инкос», 2006. 248 с.

3. Ляховицкий М. В. Методика преподавания иностранных языков : учеб. пособие для филол. вузов. Москва : Высш. школа, 1981. 159 с.

4. Носонович Е. В. Параметры аутентичного учебного текста. Иностранные языки в школе. 1999. 195 с.

5. Яковлева О. «Мовна компетенція студентства та мовна ситуація в українських ВНЗ у контексті наближення України до європейського освітнього простору». Вища освіта Украӥни. Вип. 4. Київ, 2010. С. $112-114$.

6. Kim D. A qualitative approach to the authenticity in the foreign language classroom: a study of university students learning English in Korea. Texas Papers in Foreign Language Education. 2000. № 5 (1). P. 189-205.

\section{REFERENCES}

1. Zakon Ukraini "Pro vishu osvity" [The Law of Education] // [Elektronnyi resurs]. - Rezhym dostupu: http://zakon2.rada.gov.ua/laws/show/1556-18.

2. Tarnopolskyi O.B. Metodika obycheniya inoyazschnoj rechevoj kompetentnosti v vishem uchebnom zavedenii [Methods of teaching foreign language competence at a higher educational institution]: Obr. uchebnyk / O.B. Tarnopolskyi. K.: Fyrma «Ynkos», 2006. 248 s. [in Russian]

3. Liakhovytskyi, M. V. Metodika prepodavaniya inostrannih yazikov [Methods of teaching foreign languages]: Ucheb. posobye dlia fylol. vuzov / M. V. Liakhovytskyi. M.: Vissh. shkola, 1981. 159 s. [in Russian]

4. Nosonovich, E. V. Parametri autentichnogo uchebnogo teksta [Parameters of an authentic educational text] / E. V. Nosonovich, R. P. Milrud // Inostr/ yaziki v shkole. 1999. 195 s. [in Russian]

5. Yakovleva O. «Movna kompetentsiya studenstva na movna situatsiya v ukrainskih VNZ u konteksti nablizhennya Ukraini do evropejskogo osvitnogo prostoru» [«Language competence of students and the language situation in Ukrainian universities in the context of Ukraine's approach to the European educational space»] // Vyshcha osvita Ukrainy, vyp. 4. K., 2010. S. 112-114. [in Ukranian]

6. Kim D. A qualitative approach to the authenticity in the foreign language classroom: a study of university students learning English in Korea. Texas Papers in Foreign Language Education. 2000. № 5 (1). P. 189-205. 